\title{
Potential Effects of a Modified Mediterranean Diet on Body Composition in Lipoedema
}

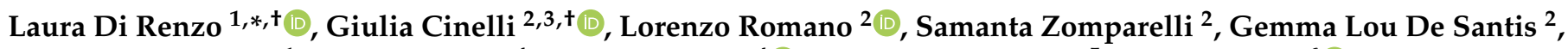 \\ Petronilla Nocerino ${ }^{1}$, Giulia Bigioni ${ }^{4}$, Lorenzo Arsini ${ }^{4}{ }^{\circledR}$, Giuseppe Cenname ${ }^{5}$, Alberto Pujia ${ }^{6}$, \\ Gaetano Chiricolo ${ }^{6}$ and Antonino De Lorenzo ${ }^{1}$ (D)
}

check for updates

Citation: Di Renzo, L.; Cinelli, G.; Romano, L.; Zomparelli, S.; Lou De Santis, G.; Nocerino, P.; Bigioni, G.; Arsini, L.; Cenname, G.; Pujia, A.; et al. Potential Effects of a Modified Mediterranean Diet on Body Composition in Lipoedema. Nutrients 2021, 13, 358. https://doi.org/ $10.3390 /$ nu13020358

Academic Editors: Jose Lara and Amelia Martí

Received: 9 December 2020

Accepted: 21 January 2021

Published: 25 January 2021

Publisher's Note: MDPI stays neutral with regard to jurisdictional claims in published maps and institutional affiliations.

Copyright: (c) 2021 by the authors. Licensee MDPI, Basel, Switzerland. This article is an open access article distributed under the terms and conditions of the Creative Commons Attribution (CC BY) license (https:/ / creativecommons.org/licenses/by/ $4.0 /)$.
1 Section of Clinical Nutrition and Nutrigenomic, Department of Biomedicine and Prevention, University of Rome Tor Vergata, Via Montpellier 1, 00133 Rome, Italy; nsanfelice02@gmail.com (P.N.); delorenzo@uniroma2.it (A.D.L.)

2 School of Specialization in Food Science, University of Rome Tor Vergata, 00133 Rome, Italy; giuliacinelli88@gmail.com (G.C.); lorenzo.romano@alumni.uniroma2.eu (L.R.); samanta.zomparelli@gmail.com (S.Z.); gemmaloudesantis@gmail.com (G.L.D.S.)

3 Predictive and Preventive Medicine Research Unit, Bambino Gesù Children's Hospital IRCCS, 00165 Rome, Italy

4 Department of Physics, University of Rome Sapienza, 00185 Rome, Italy; bigionigiulia@gmail.com (G.B.); lorenzo@arsini.it (L.A.)

5 General Command of the Carabinieri, Health Department, 00197 Rome, Italy; giuseppe.cenname@carabinieri.it

6 Department of Biomedicine and Prevention, University of Rome Tor Vergata, 00133 Rome, Italy; albpujia@gmail.com (A.P.); nucciochiricolo@gmail.com (G.C.)

* Correspondence: laura.di.renzo@uniroma2.it; Tel.: +39-349-805-2962

+ These authors contributed equally to this work.

\begin{abstract}
Lipoedema is a subcutaneous adipose tissue disease characterized by the increase in the amount and structure of fat mass (FM) in specific areas, causing pain and discomfort. 95\% of patients fail to lose weight in the lipoedema areas. The study was conducted to evaluate body composition and general health status modification in a group of lipoedema patients (LIPPY) and a control group (CTRL) after four weeks of a modified Mediterranean diet therapy (mMeD). A total of 29 subjects were included in the data analysis, divided in two groups: 14 LIPPY and 15 CTRL. After the mMeD, both groups significantly decreased their weight and body mass index; the CTRL also showed a reduction of all the circumferences and all FM's compartments. LIPPY showed a decrease of FM in upper and lower limbs. No significant differences in $\Delta \%$ between the groups were observed for the lean mass (LM). In LIPPY, an increase in the patients' ability to perform various daily physical activities related to the loss of arms' and legs' fat was observed. According to the European Quality of Life scale, the possibility for LIPPY subjects to perform simple daily activities with less fatigue, pain and anxiety is highlighted. Further long-term studies are recommended to confirm the mMeD as a good strategy for Lipoedema treatment.
\end{abstract}

Keywords: Lipoedema; SAT diseases; antioxidant diet; body composition; nutrition

\section{Introduction}

Subcutaneous Adipose Tissue (SAT) diseases are characterized by the increase in the amount and structure of fat, causing pain and discomfort. In SAT diseases, fat is resistant to weight loss following lifestyle interventions, dietary changes, surgery or pharmacologic therapy due in part to tissue fibrosis. For this reasons, SAT in SAT diseases is considered a persistent fat [1].

Although lipoedema is mostly an underrecognized condition often misdiagnosed as lymphedema or simple obesity, Child et al. presented lipoedema as a genetic condition with X-linked dominant inheritance or, more likely, autosomal dominant inheritance with 
sex limitation [2] to mostly women. The same authors revealed a prevalence within the population as 1:72,000 and men with lipoedema are extremely rare [3]. In lipoedema, lymph vessels are unable to maintain their function. The altered microcirculation leads to impaired lymph transport capacity and accumulation of lymph fluid. The high protein and fat content of lymph fluid evokes subsequent fibrosis and further deposition of fat leading to non-pitting edema characterized by the Stemmer's sign [4].

Lipoedema is classified in stages according to Herbst et al. [5], considering the quality of the skin, the presence of fibrosis, the development of a nodular or mass-like appearance of subcutaneous fat, lipomas and/or angiolipomas, inhibition of mobility and coexistence of lymphedema. Most of the patients report onset of lipoedema at menarche, with progression of the disease dependent on family history and lifestyle. Lipoedema is a disease characterized by an inflammatory condition [6,7]. From a pathophysiological point of view, the progression of lipoedema is caused by dilation and lengthening of the lymphatic channels with the development of microaneurysms. The breakdown of microaneurysms combined with the increase in interstitial fluid leads to the development of lipo-lymphedema (the last stage of lipoedema) [8]. It has been suggested that regulation of steroid hormone levels by aldo-keto reductase 1C1 (AKR1C1) plays an important role in the accumulation of subcutaneous adipose tissue. The results are consistent with AKR1C1 being the first candidate gene for lipoedema [9]. Moreover, it has been observed that the IL-6 gene polymorphism characterizes subjects with lipoedema in comparison with normal weight obese people and/or obese subjects [10,11].

Even if lipoedema is a SAT disease, body composition study is extremely useful to provide information about fat mass (FM), lean mass (LM) and bone mass of the body and subregions. A case-control study of Dietzel et al. [12] showed the usage of dual-energy X-ray absorptiometry (DXA) not only for the diagnosis of lipoedema, but particularly for monitoring specific interventions including physical exercise. Thus, changes in the amount of FM and/or LM can be quantified as objective measurable parameters at an early stage. Considering the connection between lymphatic dysfunction, adipocyte hypertrophy of SAT and the progression to lipo-lymphedema, the interventions usually applied to treat lipoedema aim to support the lymphatic flow [8]. Although lipoedema fat is resistant to lifestyle changes, there is evidence to support positive effects of exercise, particularly of aquatic therapy [13]. Due to altered microcirculation, pain, lack of mobility and psychological reasons, lipoedema management aims to facilitate patients' self-care ability, optimize health, prevent progression and modulate symptoms [14]. Psychological support and self-care, weight management, skincare protection and compression therapy are the main sectors of intervention to manage patients with lipoedema.

Improved understanding of dietary impact on outcomes of lipoedema may increase scientific and clinical awareness about the importance of nutritional approaches as well as provide directions for future research and strategies to prevent progression of this disease and the related pathologies.

Up to now, no effective nutritional treatment has been reported in patients with lipoedema, as no controlled trials have been published on this topic. Current dietary approaches are generally based on empirical data and are aimed at lowering body weight through a hypocaloric diet, inhibiting systemic inflammation with antioxidant and antiinflammatory components and reducing water retention [15]. Literature data show that weight loss did not demonstrate any significant effect on the lipoedema prognosis due to fat deposition [16]. Lipoedema fat is resistant to diet therapy and $95 \%$ of patients fail to lose weight in the lipoedema areas [17]. In insulin-resistant subjects, enhanced lipolysis and impaired lipogenesis in adipose tissue lead to the release of cytokines and lipid metabolites, ultimately promoting insulin resistance. Therefore, since no specific diet has been developed for lipoedema so far, an isoglycemic diet would seem appropriate [18]. Accordingly, the few approaches studied in literature mainly involved diets with low content of processed carbohydrates with the effect of reducing inflammation and insulin levels and therefore adipogenesis [1]. For example, it has been hypothesized that the ketogenic 
diet may be efficient in the treatment of lipoedema in terms of weight loss, reduction of edema and modulation of the inflammasome with consequent improvement of the redox state [19]. The Mediterranean diet (MD) represents a dietary pattern associated with health benefits [20], with efficacy for patients with obesity and metabolic syndrome [21]. It has been reported that micronutrients of the MD modulate the immune system and exert a protective action reducing postprandial oxidative stress and inflammation [20]. In fact, micronutrients such as polyphenols, tocopherols, resveratrol, vitamin C, vitamin A increase the antioxidant capacity of the meal and the subject's plasma antioxidant capacity [22]. Furthermore, they are able to modulate the expression of inflammation and oxidative stress-related genes [23].

Therefore, we hypothesized that a modified Mediterranean diet therapy $(\mathrm{mMeD})$ based on the typical foods of the MD, such as fruit, vegetables, legumes, whole grains, extra virgin olive oil, fish and low-fat dairy products, could be adapted for patients with lipoedema.

The main purpose of the current study was to evaluate the effects of a mMeD on weight and body composition in women with lipoedema (LIPPY - the name was chosen by the Lipoedema Italia Onlus (LIO) association for women with lipoedema) compared to a control group (CTRL). In particular, the study focuses on the FM loss in upper and lower limbs.

The second aim was to evaluate the effects of $\mathrm{mMeD}$ on the LIPPY subjects' general health status, the perception of pain, fatigue and the problems that commonly arise during the patients' daily life.

\section{Materials and Methods}

\subsection{Study Design and Subjects}

In the period between June 2019 and December 2019, we consecutively enrolled in the study all the women who voluntarily came up at the Section of Clinical Nutrition and Nutrigenomics, Department of Biomedicine and Prevention of the University of Rome Tor Vergata for nutritional medical check-up.

According to health status, the patients were separated into two groups. The LIPPY group was represented by women with the diagnosis of lipoedema made at the San Giovanni Battista Hospital in Rome (Italy); the CTRL group included patients not affected by lipoedema. For both groups, inclusion criteria were as follows: Italian Caucasian females older than 18 years old with the body mass index $(\mathrm{BMI})>18.5 \mathrm{~kg} / \mathrm{m}^{2}$; exclusion criteria were as follows: diagnosis of lymphedema, acute and chronic kidney failure, age over 65 , drug use, bariatric surgery and liposuction during the period of treatment, pregnancy and breastfeeding.

According to the inclusion criteria, the subjects eligible for study underwent a medical examination and a complete evaluation of their nutritional status, body composition and basal metabolism at baseline and after four weeks. The $\mathrm{mMeD}$ was carried out for four weeks to avoid dropout and ensure maximum adherence to treatment. Moreover, to ensure adherence to the diet, patients were monitored during the four weeks by telephone interview once a week. The patients were asked about their food intake with a 48-h recall, the possible presence of side effects and a general opinion on the satisfaction with the diet.

All the enrolled patients signed a consent form following the principles of the Declaration of Helsinki. The approval by the Ethics Committee of the Calabria Region Center Area Section (Register Protocol No. 146 17/05/2018) was obtained.

\subsection{Anthropometrics and Body Composition}

After a 12-h overnight fast, an anthropometric evaluation was carried out for each patient. Body weight and height were measured using a scale and a stadiometer (Invernizzi, Rome, Italy) while the subject was standing wearing underwear. The data were collected to the nearest $0.1 \mathrm{~kg}$ and $0.1 \mathrm{~cm}$, respectively. Neck, waist and hip circumferences were measured with a flexible and non-extensible metric tape.

BMI was calculated as body weight $(\mathrm{kg}) /$ height $(\mathrm{m})^{2}$ and classified according to the World Health Organization (WHO) [24]. A waist to hip circumferences ratio (WHR) was evaluated according to the clinical risk thresholds equivalent to WHR $>0.85$ for women [24]. 
Body composition was evaluated according to the standard method [18]. The patients were asked to remove all clothing (except underwear), shoes and any metal objects. Whole and segmental FM $(\mathrm{kg})$ was evaluated by DXA (Primus, X-ray densitometer; software version 1.2.2, Osteosys Co., Ltd., Guro-gu, Seoul, Korea) [25]. The effective radiation dose for this procedure is about $0.01 \mathrm{mSv}$. The intra- and inter-subject coefficient of variation $(\mathrm{CV} \%=100 \mathrm{SD} /$ mean) ranged from 1 to $5 \%$. The coefficients on this instrument for five participants scanned six times over a 9-month period were $2.2 \%$ for FM and $1.1 \%$ for free fat mass (FFM) and LM.

Total FM percentage (\%FM) was calculated as the total body FM (Total FM) divided by the total mass of all tissues including the total body bone (TBBone) as follows:

$$
\% \mathrm{FM}=(\text { Total FM } /(\text { Total FM + Total LM + TBBone })) \times 100
$$

According to \%FM, subjects are classified as normal weight (NW) lean women with $\% \mathrm{FM}<30 \%$; pre-obese and obese women with $\% \mathrm{FM} \geq 30 \%$ [25].

Intermuscular adipose tissue (IMAT) was calculated according to Colica et al. with the following formulas: $\log (\mathrm{IMAT})=-2.21+(0.12 \times$ fat $)+(-0.0013 \times$ fat2 $)$ for women [26]

Bioelectrical impedance analysis (BIA) (BIA101S, Akern/RJL Systems, Florence, Italy) was employed to measure resistance $(\mathrm{Rz})$, reactance $(\mathrm{Xc})$, total body water (TBW, L), extracellular body water (ECW, L) [25].

\subsection{Indirect Calorimetry}

Indirect calorimetry was performed to measure oxygen consumption $\left(\mathrm{VO}_{2}\right)$ and carbon dioxide production $\left(\mathrm{VCO}_{2}\right)$ according to De Lorenzo et al. [27] and to calculate the resting energy expenditure (REE) using a Vyntus CPX Canopy (CareFusion, Höchberg, Germany) with the Sentry Suite ${ }^{\mathrm{TM}}$ software (CareFusion, Höchberg, Germany). A gas mixture with $12.0 \% \mathrm{O}_{2}, 5.0 \% \mathrm{CO}_{2}$, balanced with $\mathrm{N}_{2}$ was used. After a steady-state condition, when no variation over $\pm 5 \%$ occurred, $\mathrm{VO}_{2}$ and $\mathrm{VCO}_{2}$ values were recorded.

The measurement was performed after fasting for $12 \mathrm{~h}$. The subjects were asked to lie down on a laboratory bed in a supine position for 25-30 $\mathrm{min}$ in a suitable room (quiet, with an ambient temperature of $22^{\circ} \mathrm{C}$ ).

The REE was determined using the Weir formula [28]:

$$
\mathrm{REE}=\left(\left(3.94 \times \mathrm{VO}_{2}\right)+\left(1.106 \times \mathrm{VCO}_{2}\right)\right) \times 1.44 .
$$

The daily energy requirements were calculated by multiplying REE by the proper physical activity level (PAL) [29].

\subsection{Dietary Assessments}

At baseline and during the $\mathrm{mMeD}$, eating habits of the subjects were evaluated through accurate data collection. Subject's food intake was assessed with a 3 days/week diet record, 2 weekdays and 1 weekend day, completed for 3 weeks, for a total of 9 days [24].

A food frequency questionnaire was used to identify the weekly frequency of intake of different foods (Appendix A) [30].

\subsection{Dietary Intervention}

All the enrolled subjects received the same hypocaloric $\mathrm{mMeD}$ with a caloric restriction of about $20 \%$ compared to the daily energy requirements, personalized according to each patient's energy requirements and LM content. Therefore, the $\mathrm{mMeD}$ considered the need of macro- and micronutrient and caloric intake based on the individual characteristics of body composition and basal metabolism. The diet indicated for each day of the week the foods to be consumed divided into 5 meals a day. The average caloric distribution of the meals was as follows: 15\%-breakfast, 10\%-morning snack, 35\%-lunch, 10\%-afternoon snack, $30 \%$-dinner. 
The mMeD's daily macronutrient intake was broken down as follows: $40-45 \%$ of total $\mathrm{kcal} /$ day of carbohydrates, $25-30 \%$ of total $\mathrm{kcal} /$ day of proteins ( $>50 \%$ of them vegetablederived), $25-30 \%$ of total kcal/day of lipids (in the total daily energy intake: saturated fat $<10 \%, 6-10 \%$ polyunsaturated fatty acids (PUFA), $n-6 / n-3$ PUFA ratio of 3:1, 15\% monounsaturated fatty acids (MUFA), $<1 \%$ trans-fatty acids) and $25 \mathrm{~g}$ of fiber.

The daily protein intake was $2 \mathrm{~g} / \mathrm{kg}$ of the total LM, according to Colica et al. [26].

The bromatological composition of the dietary intervention was obtained using the diet analyzer software package Dietosystem ${ }^{\circledR}$ (version 12.00.13, DS Medica SRL, Milan, Italy).

The main features of the $\mathrm{mMeD}$ are as follows: primarily plant-based foods such as seasonal fruits and vegetables, whole grains, legumes and nuts; replacement of butter with healthy fats such as olive oil; use of herbs and spices instead of salt; foods rich in polyunsaturated fats. Preserved and processed foods such as cold cuts, cured meats and canned products, frozen ready meals, cheese (apart from ricotta), potatoes, high glycemic index (GI) carbohydrates, alcoholic and non-alcoholic sweetened drinks were avoided.

The Mediterranean adequacy index (MAI) [31] was calculated using the ratio of the caloric intake (\%kcal/day) derived from carbohydrates and typical Mediterranean foods (like bread, pasta, vegetables, fruit, extra virgin olive oil, fish, red wine) and non-typical ones (like meat, milk and dairy products, eggs, sugar, sweets and alcohol) [32]. MAI values are considered acceptable when the value is $>5$, and $100 \%$ adequate $>15$. Oxygen radical absorbance capacity (ORAC) of the diet was calculated using the diet analyzer software package Dietosystem ${ }^{\circledR}$ (version 12.00 .13 , DS Medica SRL, Milan, Italy) to evaluate the protection provided by antioxidant compounds from food [22].

\subsection{Quality of Life}

The quality of life was assessed by using the "European Quality of Life" tool (EQ5D) $[33,34]$.

The EQ-5D consists of two distinct sections. In the first one, a subjective evaluation for 5 dimensions (mobility, self-care, daily activities, pain/discomfort and anxiety/depression) is requested. For each one, it is possible to choose a level of severity ranging from 1 to 3: level 1 (no problem); level 2 (some trouble); level 3 (extreme limitation). The combination of all the answers forms a 5-digit number that represents the patient's general health status. The three response levels for each of the 5 dimensions produce a maximum of 243 possible descriptions of the health status and allow highlighting the presence/absence of any problem and its intensity. The second section of the EQ-5D includes a visual analogue scale (VAS) graphically represented by a graduated scale ranging from 0 (the worst possible state of health) to 100 (the best possible state of health), on which a patient indicates her/his perceived level of health. For the present analysis, the scores obtained from the first and the second part at baseline and after four weeks were compared to evaluate any improvement regarding the general state of health as well as the pain, the malaise and the psychological aspects related to anxiety and depression.

\subsection{Fibromyalgia Assessment Status}

Since patients affected by lipoedema usually present pain similar to those of fibromyalgia in their body, the Fibromyalgia Assessment Status (FAS) tool was used to evaluate the effect of the diet on pain and feeling of fatigue [35]. The FAS is a simple self-administered assessment that combines the patient's evaluation of fatigue and sleep disturbance ( 2 items, score ranging from 0 to 10) and pain assessed on the basis of 16 non-articular sites listed on the self-assessment pain scale (SAPS) (score ranging from 0 to 3 ) in a unique tool.

\subsection{Statistical Analysis}

The data collected before statistical evaluations were analyzed for the presence of outliers and for normal distribution with the Shapiro-Wilk test. Outliers were not identified, and the database did not undergo any changes before performing statistical analysis. The data presented are expressed as the means \pm standard deviation and as $\Delta \%$ to evaluate 
differences between the times. At baseline, the differences between LIPPY and CTRL were assessed by the independent samples t-test and the Mann-Whitney test. Subsequently, the $\mathrm{t}$-Test for related samples or the Wilcoxon rank test were used to assess the presence of differences in the variables examined between the baseline and after four weeks. Conclusively, for each study variable, to compare the trend over time, $\Delta \%$ was calculated equal to the percentage variation of each parameter calculated as an absolute margin of variation from the baseline value. The differences in $\Delta \%$ between the baseline and after four weeks among groups were assessed with one-way ANOVA. Results were significant for $p$-value $<0.05$. All $p$-values shown are two-tailed. Statistical analysis was performed using IBM SPSS Statistics V25.0 (SPSS, Chicago, IL, USA).

\section{Results}

\subsection{Dietary Components}

At baseline, the results of analysis of dietary components (macro- and micronutrients and nutritional indexes) were calculated using the subject's food intake assessed with a 3 days/week diet record for three weeks (Table 1). The mean dietary components of the baseline diet and the $\mathrm{mMeD}$ (macro- and micronutrients and nutritional indexes) of both groups are shown in Table 1. Significant differences were highlighted for the following parameters: decreased animal proteins (\%) (LIPPY: $p<0.05$, CTRL: $p<0.0001)$, increased total fiber (g) (LIPPY and CTRL: $p<0.0001)$, decreased SFA (g) (LIPPY and CTRL: $p<0.05$ ), increased EPA (g) (LIPPY and CTRL: $p<0.05)$, increased DHA (g) (LIPPY: $p<0.0001$, CTRL: $p<0.05$ ), decreased $\omega 6 / \omega 3$ ratio (LIPPY and CTLR: $p<0.0001$ ), increased K (mg) (LIPPY: $p<0.0001$, CTRL: $p<0.05)$, increased Fe (mg) (LIPPY: $p<0.0001$, CTRL: $p<0.05)$, increased $\mathrm{Mg}(\mathrm{mg})$ (LIPPY: $p<0.0001$, CTRL: $p<0.05)$. An increase in the vitamin contents was also observed: vitamin A ( $\mu \mathrm{cg}$ ) (LIPPY and CTRL: $p<0.05)$, vitamin D ( $\mu \mathrm{cg})$ (LIPPY and CTRL: $p<0.05$ ), vitamin C (mg) (LIPPY: $p<0.0001$, CTRL: $p<0.05$ ). Finally, an increased MAI was detected when comparing baseline with the mMeD (LIPPY and CTRL: $p<0.0001$ ). No statistical differences were detected between groups.

Table 1. Dietary components (macro- and micronutrients) and nutritional indexes of the $\mathrm{mMeD}$ with respect to the baseline diet.

\begin{tabular}{|c|c|c|c|c|}
\hline & \multicolumn{2}{|c|}{ LIPPY } & \multicolumn{2}{|c|}{ CTRL } \\
\hline & Baseline & mMeD & Baseline & mMeD \\
\hline & Mean \pm SD & Mean \pm SD & Mean \pm SD & Mean \pm SD \\
\hline Energy (Kcal) & $1536.0 \pm 320.8$ & $1370.4 \pm 222.8 *$ & $1570.7 \pm 301.7$ & $1494.1 \pm 171.5$ \\
\hline Proteins (\% Kcal) & $17.6 \pm 3.8$ & $27.2 \pm 4.4^{* *}$ & $20 \pm 3.7$ & $22.5 \pm 2.04$ \\
\hline Vegetable proteins (\% Kcal) & $28.2 \pm 9.4$ & $30.2 \pm 4.6$ & $28.5 \pm 8$ & $32 \pm 8$ \\
\hline Animal proteins (\% Kcal) & $71.8 \pm 9.4$ & $62 \pm 5.3^{*}$ & $67.4 \pm 8.9$ & $52.6 \pm 5.2 * *$ \\
\hline Carbohydrates (\% Kcal) & $37.5 \pm 11.8$ & $40.2 \pm 1.6$ & $43.9 \pm 7.1$ & $43.8 \pm 3$ \\
\hline Sugars $(\% \mathrm{Kcal})$ & $13.6 \pm 4$ & $14.6 \pm 1.17$ & $15.9 \pm 4.6$ & $16.3 \pm 2$ \\
\hline Total fiber (g) & $13.8 \pm 6$ & $26.4 \pm 4^{* *}$ & $19.7 \pm 4.3$ & $28.9 \pm 3.6^{* *}$ \\
\hline Lipids (\% Kcal) & $44.4 \pm 9.6$ & $31.9 \pm 3.6^{*}$ & $36.1 \pm 7$ & $33.5 \pm 3.1$ \\
\hline SFA $(g)$ & $18.2 \pm 6.9$ & $9.4 \pm 2.2 *$ & $17.5 \pm 7.9$ & $12.6 \pm 3 *$ \\
\hline PUFA (g) & $8.6 \pm 3.4$ & $9.05 \pm 4$ & $6.9 \pm 1.7$ & $8.2 \pm 1.5^{*}$ \\
\hline PUFA/SFA & $0.47 \pm 0.2$ & $0.93 \pm 0.2^{* *}$ & $1.7 \pm 3$ & $0.64 \pm 0.2$ \\
\hline MUFA (g) & $36.1 \pm 13.4$ & $23.4 \pm 5.9 *$ & $32 \pm 9.7$ & $28.1 \pm 4.9$ \\
\hline EPA $(\mathrm{g})$ & $0.13 \pm 0.21$ & $0.53 \pm 0.27 *$ & $0.10 \pm 0.20$ & $0.40 \pm 0.11 *$ \\
\hline DHA (g) & $0.20 \pm 0.40$ & $1.1 \pm 0.46^{* *}$ & $0.22 \pm 0.54$ & $0.62 \pm 0.24$ * \\
\hline$\omega 6 / \omega 3$ & $8.04 \pm 3.2$ & $2.6 \pm 0.54^{* *}$ & $6.1 \pm 1.8$ & $3.5 \pm 1^{* *}$ \\
\hline Oleic acid (g) & $29.7 \pm 12$ & $23.3 \pm 5.5$ & $30.7 \pm 9.3$ & $27 \pm 4.7$ \\
\hline $\mathrm{Na}(\mathrm{mg})$ & $1210 \pm 996.7$ & $957.4 \pm 236.1$ & $1435.5 \pm 677.4$ & $1278.8 \pm 203.7$ \\
\hline $\mathrm{K}(\mathrm{mg})$ & $2270.7 \pm 655.5$ & $3549.1 \pm 342.1 * *$ & $2871.8 \pm 631.1$ & $3637.1 \pm 390.2 *$ \\
\hline $\mathrm{Fe}(\mathrm{mg})$ & $9.7 \pm 3.2$ & $15.1 \pm 2.17^{* *}$ & $10.5 \pm 2$ & $13.6 \pm 1.81 *$ \\
\hline $\mathrm{Mg}(\mathrm{mg})$ & $162.7 \pm 75.5$ & $295.8 \pm 37.2 * *$ & $227.5 \pm 94$ & $304.1 \pm 48.3^{*}$ \\
\hline
\end{tabular}


Table 1. Cont.

\begin{tabular}{ccccc}
\hline & \multicolumn{2}{c}{ LIPPY } & & CTRL \\
\hline & Baseline & mMeD & Baseline & mMeD \\
\hline & Mean \pm SD & Mean \pm SD & Mean \pm SD & Mean \pm SD \\
\hline Vit. A $(\mu \mathrm{cg})$ & $764.3 \pm 329.7$ & $1091.3 \pm 71.2^{*}$ & $930.6 \pm 306$ & $1281.2 \pm 455.9^{*}$ \\
Vit. C $(\mathrm{mg})$ & $112 \pm 48.5$ & $190.2 \pm 14.7^{* *}$ & $145.4 \pm 62.20$ & $224.5 \pm 38.2^{*}$ \\
Vit. D $(\mu \mathrm{cg})$ & $4.3 \pm 4.4$ & $7.63 \pm 2.5^{*}$ & $2.3 \pm 3.8$ & $5.3 \pm 2 *$ \\
Vit. E $(\mathrm{mg})$ & $11.7 \pm 2.2$ & $12.6 \pm 2$ & $5.3 \pm 11.8$ & $14.7 \pm 1.6$ \\
ORAC $(\mu \mathrm{mol})$ & $2423.0 \pm 1814.0$ & $13538.0 \pm 1517.0^{* *}$ & $11759.0 \pm 6910.0$ & $14105.0 \pm 1584.0$ \\
MAI & $1.4 \pm 0.7$ & $14.7 \pm 0.7^{* *}$ & $1.45 \pm 1.07$ & $14.06 \pm 1.9 * *$ \\
\hline
\end{tabular}

SFA, saturated fatty acid; PUFA, polyunsaturated fatty acid; MUFA, monounsaturated fatty acid; EPA, eicosapentaenoic acid; DHA, docosahexaenoic acid; $\mathrm{Na}$, sodium; K, potassium; Fe, iron; Mg, magnesium; Vit., vitamin; ORAC, oxygen radical absorbance capacity; MAI, Mediterranean adequacy index; $\mathrm{mMeD}$, modified Mediterranean diet therapy. The paired t-test was performed to compare dietary intake of the baseline diet and of the mMeD. ${ }^{*} p<0.05 ;{ }^{* *} p<0.0001$.

\subsection{Anthropometry and Body Composition}

Of the 40 enrolled subjects, 34 met the inclusion criteria; five of them declined to participate. Finally, 29 subjects were included in the data analysis and divided into two groups: 14 patients in the LIPPY group and 15 patients in the CTRL group.

Figure 1 depicts different stages of lipoedema identified in the LIPPY group: $14.3 \%$ of the patients were in stage $1,42.8 \%$ of them were in stage $2,28.6 \%$ of them were in stage 3 , $14.3 \%$ of them were in stage 4 .

At baseline, no statistical differences were observed between groups for age, height, weight, BMI, circumferences, Rz, TBW parameters. However, WHR, $\mathrm{X}_{\mathrm{c}}$ and ECW were significantly different $(p=0.029 ; p=0.001 ; p=0.012 ; p=0.006$, respectively) between the two groups (data not shown).

The intra- and inter-group $(\Delta \%)$ comparison of anthropometric, bioimpedance and metabolic parameters at baseline and after four weeks of the $\mathrm{mMeD}$ is shown in Table 2. After the $\mathrm{mMeD}$, in the CTRL group, weight, BMI, neck, waist, hip circumference and WHR were significantly reduced $(p=0.001 ; p=0.002 ; p=0.012 ; p=0.003 ; p=0.002 ; p=0.040)$. In the LIPPY group, weight and BMI were significantly reduced ( $p=0.025 ; p=0.021)$. For both groups, no other statistical differences were observed after four weeks of the $\mathrm{mMeD}$. A significant difference in the waist circumference $\Delta \%$ between the LIPPY and CTRL groups was observed $(p=0.022)$.

At baseline, legs' FM $(\mathrm{kg}), \mathrm{LM}(\mathrm{kg})$, total mass $(\mathrm{kg})$ and fat region (\%) were statistically different between the two groups ( $p=0.013 ; p=0.029 ; p=0.008 ; p=0.019$, respectively).

The intra- and inter-group $(\Delta \%)$ comparison of body composition parameters by DXA at baseline and after four weeks of the $\mathrm{mMeD}$ are shown in Table 3. After four weeks of the $\mathrm{mMeD}$, a significant decrease of most of the analyzed parameters was highlighted in the CTRL group. In the LIPPY group, unlike in the CTRL group, the total fat free mass and the legs' total mass $(\mathrm{kg})$ were significantly reduced $(p=0.001 ; p=0.011)$. Conversely, for both groups, the arms' and legs' FM (kg) had a significant decrease after four weeks of the mMeD (LIPPY: arms, $4.06 \pm 1.88$ to $3.70 \pm 1.47, p=0.048 ;$ legs, $18.17 \pm 8.52$ to $15.91 \pm 6.96$, $p=0.007$; CTRL: arms, $3.21 \pm 0.99$ to $2.96 \pm 1.02, p=0.046$; legs, $11.01 \pm 3.66$ to $10.22 \pm 3.24$, $p=0.004$ ) (Figure 2). No difference in $\Delta \%$ between the groups was found (arms' FM $\Delta \%$ : CTRL, $-7.79 \pm 15.12$; LIPPY, $-6.66 \pm 10.61 ; p=0.841 ;$ legs' FM $\Delta \%$ : CTRL,$-6.90 \pm 6.23$; LIPPY, $-8.76 \pm 7.20 ; p=0.499$ ).

Comparing $\triangle \%$ of the parameters between the LIPPY and the CTRL groups at baseline and after the mMeD, significant differences in trunk FM $(\mathrm{kg})$, total body FM $(\mathrm{kg})$, trunk total mass $(\mathrm{kg})$, trunk fat region $\%$ and IMAT were observed $(p=0.012 ; p=0.042 ; p=0.026$; $p=0.029 ; p=0.006)($ Table 3$)$. 


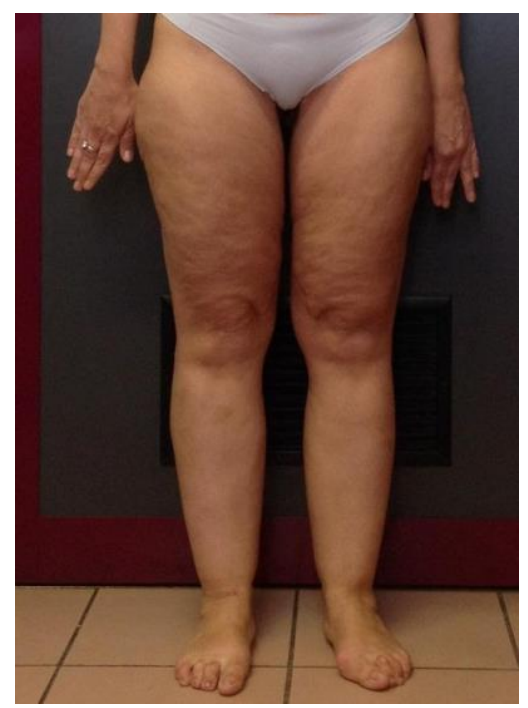

(a)

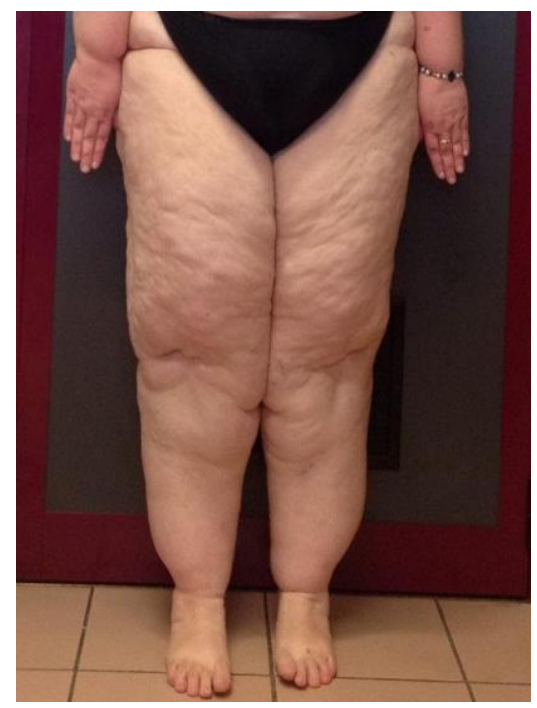

(c)

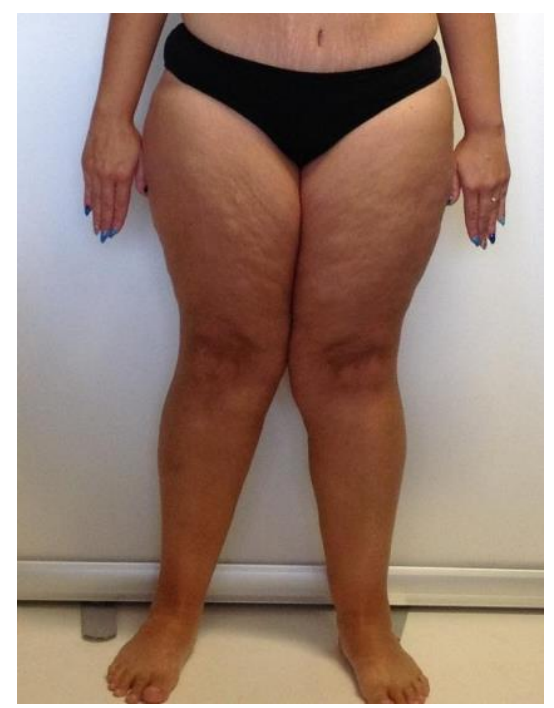

(b)

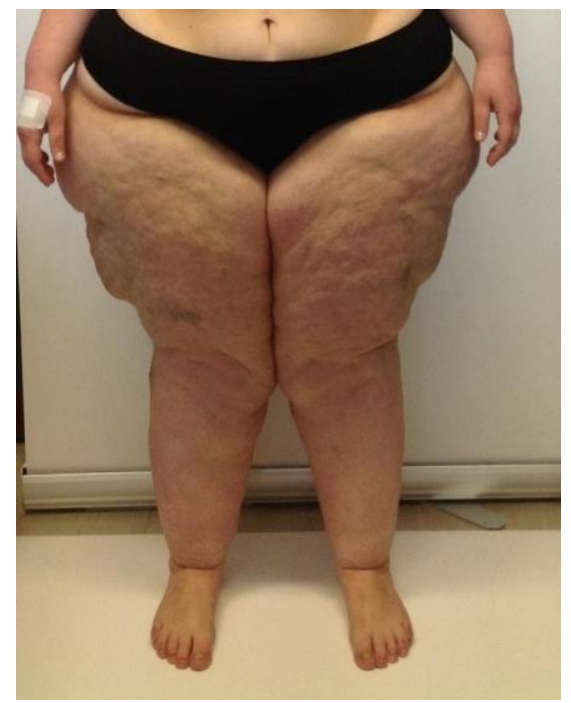

(d)

Figure 1. Pictures of different stages of lipoedema. (a) Stage 1: the skin is still smooth and appears normal but with pain, bruising and nodules in the fat tissue. (b) Stage 2: the skin is characterized by a mattress-like pattern with the presence of fibrosis, development of nodular or mass-like appearance of the subcutaneous fat, lipomas and/or angiolipomas. (c); Stage 3 involves the loss in elasticity, inhibition of mobility, inflammation followed by constant and palpable fibrosis. (d) Stage 4: presence of both lipoedema and lymphoedema.

\subsection{Quality of Life and Fibromyalgia}

The EQ-5D highlighted a significant improvement of the perceived quality of life in the lipoedema patients, with the total score decreasing from an average value of $8.3 \pm 1.8$ at baseline to a value of $6.9 \pm 1.4$ after four weeks of treatment $(p<0.05)$. No clinically significant modification were observed regarding the VAS (baseline: $64.7 \pm 18.3$; 4 weeks: $69.9 \pm 18.3 ; p=0.47)$, the fibromyalgia severity scale index $(p=0.21)$ and the Fibromyalgia Assessment Status scale $(p=0.75)$. No significant results were observed in the CTRL group related to EQ-5D, VAS, fibromyalgia severity scale index and Fibromyalgia Assessment Status scale, probably because these subjects did not usually experience pain or other discomfort in their daily life (data not shown). 
Table 2. Comparison of anthropometric, indirect calorimetry and bioimpedance variables between the baseline and after four weeks.

\begin{tabular}{|c|c|c|c|c|c|c|c|c|c|}
\hline \multirow{3}{*}{ Parameters } & \multicolumn{3}{|c|}{ CTRL } & \multicolumn{3}{|c|}{ LIPPY } & \multicolumn{3}{|c|}{$\Delta \%$ Baseline-4 Weeks } \\
\hline & Baseline & 4 Weeks & & Baseline & 4 Weeks & & CTRL & LIPPY & \\
\hline & Mean \pm SD & Mean \pm SD & $p$ & Mean \pm SD & Mean \pm SD & $p$ & Mean \pm SD & Mean \pm SD & $p$ \\
\hline Weight (kg) & $73.45 \pm 14.50$ & $70.21 \pm 14.09$ & $0.001^{* *}+$ & $91.06 \pm 28.63$ & $88.1 \pm 27.7$ & $0.025 *+$ & $-4.37 \pm 3.94$ & $-3.04 \pm 4.75$ & 0.418 \\
\hline $\operatorname{BMI}\left(\mathrm{kg} / \mathrm{m}^{2}\right)$ & $27.52 \pm 5.22$ & $26.38 \pm 4.99$ & $0.002^{* *}+$ & $35.50 \pm 12.17$ & $34.36 \pm 11.84$ & $0.021 *+$ & $-4.05 \pm 4.03$ & $-3.04 \pm 4.75$ & 0.540 \\
\hline Neck C. $(\mathrm{cm})$ & $35.50 \pm 3.16$ & $34.77 \pm 3.08$ & $0.012 *$ & $37.21 \pm 3.59$ & $36.79 \pm 2.96$ & 0.443 & $-2.12 \pm 2.45$ & $-0.89 \pm 5.32$ & 0.469 \\
\hline Waist C. (cm) & $85.12 \pm 13.37$ & $80.24 \pm 10.67$ & $0.003 * *$ & $87.18 \pm 16.08$ & $85.44 \pm 14.44$ & 0.115 & $-5.43 \pm 4.33$ & $-1.66 \pm 3.84$ & 0.022 * \\
\hline Hip C. (cm) & $108.08 \pm 9.87$ & $105.19 \pm 9.06$ & $0.002^{* *}+$ & $122.11 \pm 23.31$ & $120.68 \pm 21.76$ & $0.250+$ & $-2.59 \pm 2.55$ & $-0.95 \pm 3.89$ & 0.198 \\
\hline $\mathrm{VO} 2(\mathrm{ml} / \mathrm{min})$ & $218.87 \pm 31.61$ & $213.57 \pm 36.55$ & 0.323 & $217.14 \pm 46.08$ & $213.17 \pm 40.93$ & 0.515 & $-2.02 \pm 7.01$ & $-1.57 \pm 14.29$ & 0.919 \\
\hline $\mathrm{VCO} 2(\mathrm{ml} / \mathrm{min})$ & $182.13 \pm 29.55$ & $181.36 \pm 31.38$ & 0.752 & $173.57 \pm 41.52$ & $172.75 \pm 32.64$ & 0.972 & $0.13 \pm 2.51$ & $2.36 \pm 20.9$ & 0.694 \\
\hline MREE (kcal) & $1508.00 \pm 247.11$ & $1502.79 \pm 260.49$ & 0.677 & $1479.21 \pm 321.51$ & $1454.83 \pm 281.4$ & 0.633 & $0.24 \pm 2.68$ & $-0.88 \pm 15.18$ & 0.789 \\
\hline $\mathrm{Rz}$ & $561.60 \pm 75.80$ & $569.33 \pm 77.56$ & 0.320 & $507.64 \pm 86.63$ & $510 \pm 94.72$ & 0.779 & $1.53 \pm 5.02$ & $0.43 \pm 6.25$ & 0.603 \\
\hline $\mathrm{X}_{\mathrm{c}}$ & $59.87 \pm 9.62$ & $58.27 \pm 9.60$ & 0.411 & $46.64 \pm 9.37$ & $49.71 \pm 14.62$ & 0.344 & $-2.21 \pm 11.29$ & $7.07 \pm 24.27$ & 0.193 \\
\hline TBW (L) & $34.89 \pm 4.66$ & $34.37 \pm 4.53$ & $0.800+$ & $37.99 \pm 5.84$ & $37.79 \pm 5.97$ & $0.396+$ & $-1.43 \pm 2.82$ & $-0.54 \pm 3.7$ & 0.469 \\
\hline ECW (L) & $15.80 \pm 2.08$ & $16.00 \pm 2.22$ & 0.522 & $18.88 \pm 3.37$ & $18.35 \pm 3.73$ & 0.433 & $1.48 \pm 8.03$ & $-2.49 \pm 13.00$ & 0.328 \\
\hline $\mathrm{BCM}(\mathrm{kg})$ & $25.93 \pm 4.98$ & $24.82 \pm 3.65$ & 0.110 & $25.12 \pm 3.66$ & $25.68 \pm 4.85$ & 0.559 & $-3.45 \pm 7.77$ & $2.39 \pm 14.53$ & 0.184 \\
\hline $\mathrm{PA}\left({ }^{\circ}\right)$ & $6.13 \pm 1.08$ & $5.85 \pm 0.61$ & $0.008^{* *}+$ & $5.24 \pm 0.59$ & $5.54 \pm 1.24$ & $0.683+$ & $-3.01 \pm 11.44$ & $6.15 \pm 22.28$ & 0.171 \\
\hline
\end{tabular}

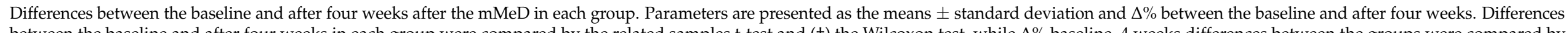

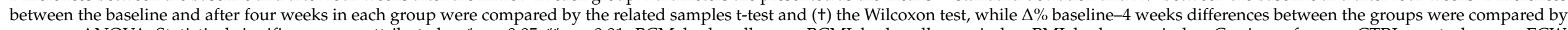

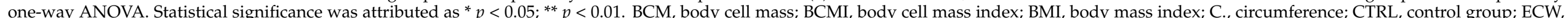

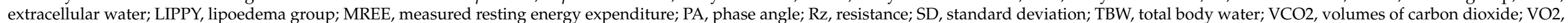

volumes of oxygen; WHR: waist-to-hip Ratio; $X_{\mathrm{C}}$, reactance. 
Table 3. Comparison of body composition variables between the baseline and after four weeks.

\begin{tabular}{|c|c|c|c|c|c|c|c|c|c|}
\hline \multirow{3}{*}{ Parameters } & \multicolumn{3}{|c|}{ CTRL } & \multicolumn{3}{|c|}{ LIPPY } & \multicolumn{3}{|c|}{$\Delta \%$ Baseline -4 Weeks } \\
\hline & Baseline & 4 Weeks & & Baseline & 4 Weeks & & CTRL & LIPPY & \\
\hline & Mean \pm SD & Mean \pm SD & $p$ & Mean \pm SD & Mean \pm SD & $p$ & Mean \pm SD & Mean \pm SD & $p$ \\
\hline Fat mass, trunk (kg) & $14.09 \pm 5.97$ & $12.39 \pm 6.03$ & $0.001 * *$ & $18.66 \pm 11.71$ & $17.64 \pm 11.23$ & 0.220 & $-13.77 \pm 12.44$ & $-0.81 \pm 10.17$ & 0.012 * \\
\hline Fat mass, android (kg) & $2.26 \pm 1.14$ & $2.05 \pm 1.14$ & $0.003^{* *}$ & $3.08 \pm 2.06$ & $3.08 \pm 2.47$ & 0.717 & $-11.95 \pm 13.31$ & $-1.14 \pm 17.68$ & 0.094 \\
\hline Fat mass, gynoid $(\mathrm{kg})$ & $5.43 \pm 1.74$ & $4.92 \pm 1.67$ & $0.001^{* *}+$ & $7.81 \pm 4.33$ & $7.16 \pm 3.68$ & $0.074 \dagger$ & $-9.88 \pm 7.44$ & $-4.27 \pm 8.49$ & 0.094 \\
\hline Fat mass, total body $(\mathrm{kg})$ & $29.2 \pm 9.8$ & $26.4 \pm 9.49$ & $0.001^{* *+}$ & $42.02 \pm 21.94$ & $39.25 \pm 20.24$ & $0.114+$ & $-9.94 \pm 8.86$ & $-3.10 \pm 5.65$ & 0.042 * \\
\hline Lean mass, arms (kg) & $4.49 \pm 0.97$ & $4.40 \pm 1.02$ & $0.117+$ & $4.41 \pm 0.78$ & $4.06 \pm 0.68$ & $0.225+$ & $-2.16 \pm 4.87$ & $-4.52 \pm 11.13$ & 0.473 \\
\hline Lean mass, legs (kg) & $14.82 \pm 2.58$ & $14.46 \pm 2.64$ & $0.023 *$ & $17.13 \pm 2.83$ & $15.87 \pm 2.81$ & 0.083 & $-2.49 \pm 3.81$ & $-4.45 \pm 6.96$ & 0.373 \\
\hline Lean mass, trunk $(\mathrm{kg})$ & $19.31 \pm 2.88$ & $19.47 \pm 2.95$ & 0.516 & $21.42 \pm 4.22$ & $21.42 \pm 4.26$ & 0.126 & $0.90 \pm 5.00$ & $3.47 \pm 6.13$ & 0.263 \\
\hline Lean mass, total body (kg) & $41.74 \pm 6.27$ & $41.38 \pm 6.32$ & 0.367 & $46.65 \pm 7.99$ & $45.74 \pm 7.43$ & 0.366 & $-0.85 \pm 3.52$ & $1.89 \pm 4.43$ & 0.099 \\
\hline Total mass, arms (kg) & $8.01 \pm 1.82$ & $7.65 \pm 1.89$ & $0.043 *$ & $8.74 \pm 2.54$ & $8.02 \pm 1.93$ & 0.083 & $-4.31 \pm 7.90$ & $-5.94 \pm 8.70$ & 0.632 \\
\hline Total mass, legs (kg) & $26.65 \pm 5.58$ & $26.18 \pm 5.06$ & 0.485 & $36.15 \pm 10.62$ & $32.64 \pm 9.53$ & 0.011 * & $-1.01 \pm 11.38$ & $-6.87 \pm 5.54$ & 0.145 \\
\hline Total mass, trunk (kg) & $34.13 \pm 7.73$ & $32.58 \pm 7.66$ & $0.006^{* *}$ & $40.86 \pm 15.33$ & $39.93 \pm 14.93$ & 0.917 & $-4.55 \pm 5.44$ & $1.12 \pm 6.40$ & 0.026 * \\
\hline Total mass, android (kg) & $5.12 \pm 1.45$ & $4.93 \pm 1.45$ & $0.028 *$ & $6.38 \pm 2.63$ & $6.53 \pm 3.69$ & 0.456 & $-4.00 \pm 6.14$ & $3.29 \pm 17.09$ & 0.141 \\
\hline Total mass, gynoid (kg) & $12.12 \pm 2.4$ & $11.49 \pm 2.36$ & $0.001^{* *}$ & $15.27 \pm 5.58$ & $14.27 \pm 4.78$ & 0.293 & $-5.17 \pm 4.81$ & $-2.85 \pm 8.14$ & 0.380 \\
\hline Fat region $\%$, arms & $39.75 \pm 5.61$ & $38.06 \pm 6.79$ & 0.106 & $44.16 \pm 10.39$ & $44.61 \pm 9.55$ & 0.467 & $-4.27 \pm 9.87$ & $-0.72 \pm 6.35$ & 0.326 \\
\hline Fat region $\%$, legs & $40.6 \pm 6.32$ & $39.44 \pm 6.20$ & $0.029 *$ & $48.19 \pm 9.48$ & $47.3 \pm 8.43$ & 0.183 & $-2.86 \pm 4.67$ & $-1.57 \pm 4.36$ & 0.492 \\
\hline Fat region $\%$, gynoid & $43.95 \pm 6.90$ & $41.88 \pm 7.39$ & $0.003^{* *}$ & $48.20 \pm 11.03$ & $47.65 \pm 9.34$ & 0.121 & $-4.98 \pm 5.93$ & $-1.84 \pm 4.29$ & 0.164 \\
\hline Fat region $\%$, total body & $39.02 \pm 7.13$ & $36.78 \pm 7.57$ & $0.002 * *$ & $42.78 \pm 11.63$ & $42.5 \pm 10.08$ & 0.796 & $-6.07 \pm 6.45$ & $1.15 \pm 11.92$ & 0.061 \\
\hline IMAT & $1.14 \pm 0.43$ & $1.02 \pm 0.45$ & $0.004^{* *}$ & $1.37 \pm 0.54$ & $1.35 \pm 0.54$ & 0.674 & $-11.57 \pm 11.88$ & $0.74 \pm 5.38$ & $0.006^{* *}$ \\
\hline
\end{tabular}

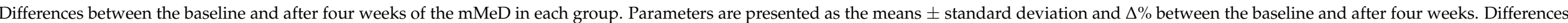

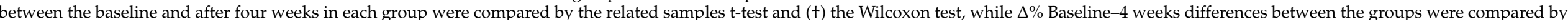
one-way ANOVA. Statistical significance was attributed as ${ }^{*} p<0.05 ; * *<0.01$. CTRL, control group; IMAT, intermuscular adipose tissue; LIPPY, lipoedema group; SD, standard deviation. 


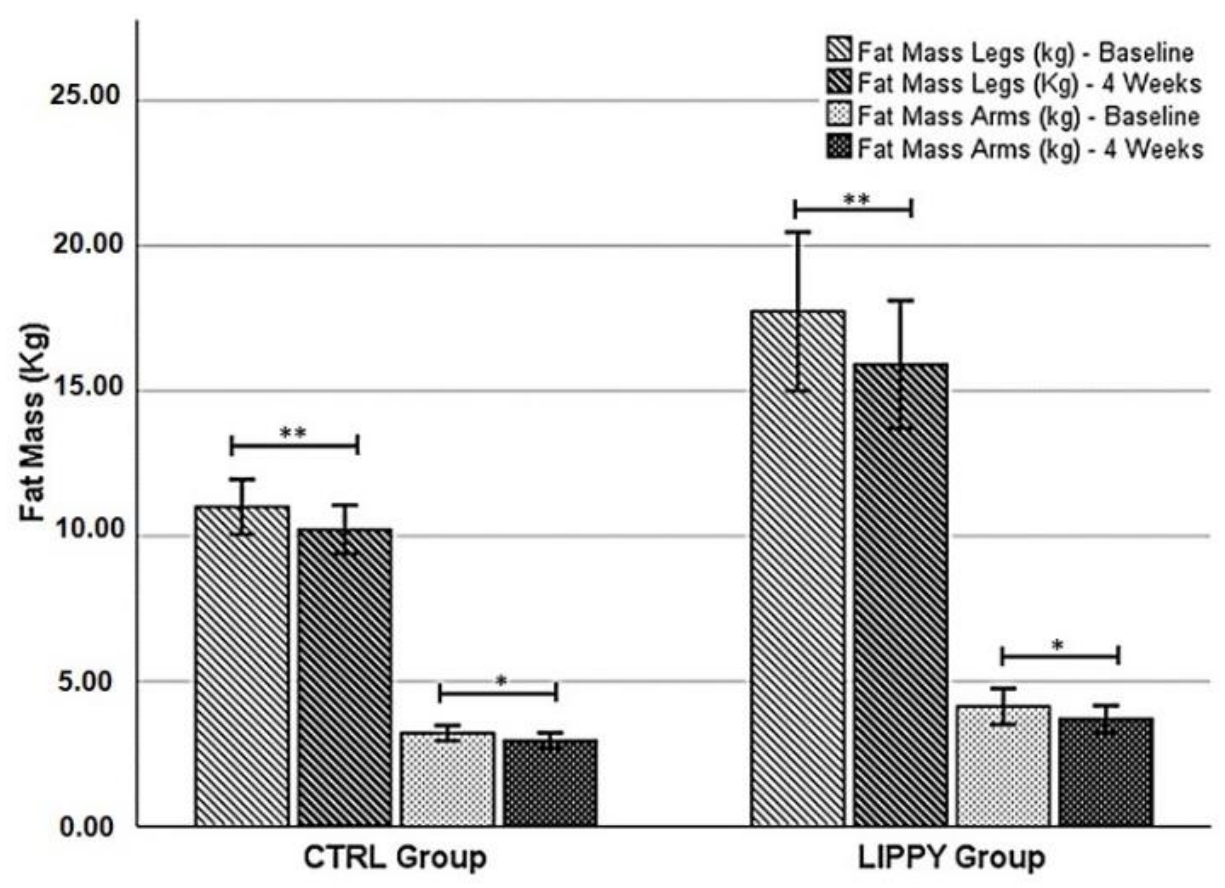

Figure 2. Differences between the baseline and after four weeks of the $\mathrm{mMeD}$ in each group for the legs' and arms' fat mass. Statistical significance was attributed as ${ }^{*} p<0.05 ;{ }^{* *} p<0.01$.

\section{Discussion}

For the improvement of the quality of life of LIPPY patients, it is essential to find a dietary strategy that can be accepted and followed, aimed not only at weight loss and reducing FM in the areas of the lower and upper limbs, but above all at the reduction of pain that is accompanied by the expansion of inflamed subcutaneous tissue and orthostatic edema [36,37]. Moreover, weight gain should be avoided to prevent edema worsening [38].

The main aim of lipoedema treatment should also target factors which negatively influence lipoedema (such as obesity, the presence of lymphatic or venous edema, incorrect insight into the condition and decreased level of physical activity). It was therefore hypothesized that a low-calorie diet plan based on foods rich in antioxidant and antiinflammatory molecules [22] could contribute to the well-being of LIPPY patients and healthy lifestyle [39]. Therefore, the goal of the $\mathrm{mMeD}$ was to reduce consumption of saturated fatty acids and preserved foods [20]. The mMeD included wholesome foods, mostly plant-based, a large number of vegetables and fruits and fermented foods to obtain an increase in ORAC units per day and the right dosage of food antioxidants [22]. Moreover, sugars, chemically modified fats and processed foods were eliminated. Animal proteins were decreased in favor of plant-based proteins (Table 1 ). The $\omega 6 / \omega 3$ ratio was markedly changed with respect to the baseline (LIPPY and CTRL: $p<0.0001)$ thanks to the addition of foods with a high concentration of omega-3 polyunsaturated fatty acids such as fish and nuts that play an important role in the regulatory process of inflammation by promoting an anti-inflammatory effect [21]. As fibers are involved in the modulation process of inflammation, immune system and microbiota equilibrium [22], fiber consumption from fruits and whole grains was significantly increased with respect to the baseline (LIPPY and CTRL: $p<0.0001)$. The $\mathrm{mMeD}$ content of molecules with antioxidant and anti-inflammatory activity [32] such as vitamins A (LIPPY and CTRL: $p<0.05$ ), C (LIPPY: $p<0.0001$, CTRL: $p<0.05$ ), D (LIPPY and CTRL: $p<0.05$ ) and minerals [40-42] was significant increased with respect to the baseline, with amelioration of the MAI index (LIPPY and CTRL: $p<0.0001$ ).

At baseline, no differences in age and anthropometric parameters were observed between the two groups. However, LIPPY women had significantly higher values of leg compartments with respect to the CTRL group (data not shown), as already expected for 
this pathology. Moreover, the FM ( $\mathrm{kg}$ and \%) of legs and the FM (\%) of arms were higher in the LIPPY group with respect to the CTRL, confirming that lipoedema affects mainly upper and lower limbs. Therefore, an expected result was WHR lower in the LIPPY group than in the CTRL group due to characteristic fat deposition of this disease [43]. Regarding the BIA results, the LIPPY group presented lower $X_{C}$ values with respect to the CTRL group, and consequently a higher ECW value. This is probably related to increased fat deposition in legs with a consequent expansion of the ECW compartment [44].

In both groups, weight and BMI were significantly decreased after four weeks of the $\mathrm{mMeD}$ without differences in $\Delta \%$ between the two groups (Table 2 ). In the CTRL group, weight loss was reflected in reduction of all body composition parameters and related circumferences. After the mMeD, LIPPY patients showed only a decrease of FM in upper and lower limbs and a decrease of LM in legs, without significant differences in $\Delta \%$ with respect to the CTRL group (Table 3). In the CTRL group, we observed that truncal fat was the compartment characterized by the highest loss, as previously demonstrated [25,45]. Moreover, our results do not confirm the statement of Wold et al. [46], according to whom women affected by lipoedema are characterized by low REE [27,47].

Although the loss of FM in the upper and lower limbs was observed in both groups, the statistical non-significance of $\Delta \%$ reinforces the observed data. For the first time a diet such as the mMeD has been shown to be effective in reducing FM in the typical points of lipoedema, such as in women not affected by this disease. Loss of upper and lower limbs' fat can probably be the key to decreasing symptoms in lipoedema. For the first time, an increase in the LIPPY patients' ability to perform various daily physical activities after a diet therapy was observed. According to the EQ-5D scale results, the possibility of those patients to perform simple daily activities with less fatigue, pain and anxiety is highlighted due to their body condition probably improving their perception of the quality of life. This might reflect a positive response to the $\mathrm{mMeD}$, allowing a higher quality of daily life [11].

The limitations of the study were the small number of participants, though the number of patients is sufficient for rare pathology studies such as lipoedema-and short intervention period. Therefore, we enrolled all the available patients without differentiating them by disease stages and determining as a consequence a wide variance in BMI. Since lipoedema is a rare adipose disorder characterized by expansion of the SAT, the BMI cannot be considered an indicator of obesity, as obesity itself may or may not overlap. The intervention period was a mandatory choice because it was the period of greatest adherence to the prescribed diet therapy. Despite the bias linked to the self-reporting of dietary intake, the data discussed make it possible to notice that the $\mathrm{mMeD}$ showed increased antioxidant and antiinflammatory nutritional indexes. However, more data are needed for a larger population, and long-term interventions are required. Moreover, future studies of different types of diet therapies such as low-carb, high-fat or focused on specific antioxidant micronutrients, as compared to a control group following a normal diet, will be necessary to evaluate efficacy of pain management as related to weight and FM loss. Finally, in order to evaluate the antioxidant and anti-inflammatory effect of the diet, further studies directly measuring the inflammatory and oxidative status of the patients should be performed.

In conclusion, the strength of this study was the adherence of LIPPY patients to the $\mathrm{mMeD}$; this improved overall nutritional status and quality of life, reducing weight, arms and legs' FM. Although more studies are recommended to investigate whether the increase in the antioxidant capacity corresponds to weight loss, our study highlighted that the $\mathrm{mMeD}$ with high values of MAI [48] and ORAC [22] could be a nutritional strategy for lipoedema treatment.

Author Contributions: Conceptualization, L.D.R.; data curation, G.C. (Giulia Cinelli), G.B. and L.A; formal analysis, G.C. (Giulia Cinelli), G.B., L.A and L.R.; investigation, S.Z., G.L.D.S., A.P., P.N., G.C. (Giulia Cinelli), G.C. (Gaetano Chiricolo) and G.C. (Giuseppe Cenname); methodology, L.D.R.; project administration, L.D.R.; supervision, A.D.L.; validation, G.C. (Giulia Cinelli), G.B., L.A. and L.R.; writing—original draft, L.D.R. and G.C. (Giulia Cinelli); writing—review and editing, L.D.R., 
G.C.(Giulia Cinelli), L.R., G.L.D.S. All authors have read and agreed to the published version of the manuscript.

Funding: This research received no external funding.

Institutional Review Board Statement: The study was conducted according to the guidelines of the Declaration of Helsinki, and approved by the Institutional Review Calabria Region Center Area Section (Register Protocol No. 146 17/05/2018).

Informed Consent Statement: Informed consent was obtained from all subjects involved in the study.

Data Availability Statement: The data presented in this study are available on request from the corresponding author. The data are not publicly available due to privacy.

Acknowledgments: The authors thank all the LIPPY and control subjects who participated as volunteers in the study. The authors thank Silvia Iannuccelli for planning the diet and the staff of the Section of Clinical Nutrition and Nutrigenomic, Department of Biomedicine and Prevention, University of Rome Tor Vergata, for supporting the study. The authors thank LIO (Lipoedema Italia Onlus) for participation in the clinical trial. The authors thank Sandro Michelini for the diagnosis of lipoedema. The authors thank Fulvia Mariotti and Oliverio Plazzi Marzotto for English revision.

Conflicts of Interest: The authors declare no conflict of interest.

$\begin{array}{ll}\text { Abbreviations } \\ \text { BCM } & \text { Body Cell Mass } \\ \text { BCMI } & \text { Body Cell Mass Index } \\ \text { BIA } & \text { Bioelectrical impedance analysis } \\ \text { BMI } & \text { Body Mass Index } \\ \text { CTRL } & \text { Control Group } \\ \text { DHA } & \text { Docosahexaenoic Acid } \\ \text { DXA } & \text { Dual-Energy X-Ray Absorptiometry } \\ \text { ECW } & \text { Extracellular Water } \\ \text { EPA } & \text { Eicosapentaenoic Acid } \\ \text { Fe } & \text { Iron } \\ \text { FFM } & \text { Free Fat Mass } \\ \text { FM } & \text { Fat Mass } \\ \text { IMAT } & \text { Intermuscular Adipose Tissue } \\ \text { K } & \text { Potassium } \\ \text { LIPPY } & \text { Lipoedema Group } \\ \text { LM } & \text { Lean Mass } \\ \text { MAI } & \text { Mediterranean Adequacy Index } \\ \text { mMeD } & \text { Modified Mediterranean Diet Therapy } \\ \text { Mg } & \text { Magnesium } \\ \text { MREE } & \text { Measured Resting Energy Expenditure } \\ \text { MUFA } & \text { Monounsaturated Fatty Acid } \\ \text { Na } & \text { Sodium } \\ \text { ORAC } & \text { Oxygen Radical Absorbance Capacity } \\ \text { PA } & \text { Phase Angle } \\ \text { PUFA } & \text { Polyunsaturated Fatty Acid } \\ \text { Rz } & \text { Resistance } \\ \text { Xc } & \text { Reactance } \\ \text { SFA } & \text { Saturated Fatty Acid } \\ \text { TBW } & \text { Total Body Water } \\ \text { VCO2 } & \text { Volumes of Carbon Dioxide } \\ \text { Vit. } & \text { Vitamin } \\ \text { VO2 } & \text { Volumes of Oxygen } \\ \text { WHR } & \text { Waist-to-Hip Ratio } \\ & \\ & \end{array}$




\section{Appendix A. Medium-Length FFQs}

MEDIUM-LENGTH FOOD FREQUENCY QUESTIONNAIRE

\section{A. DRINKS}

1. Do you drink COFFEE? Yes

No, never.

How many times per day? ... .......

2. Do you drink ALCOHOL DRINKS?

$\begin{array}{lll}\text { How much? } & \text { Wine: } & 0.15 \mathrm{~L} \quad \square \\ & \text { Beer: } & 0.23 \mathrm{~L} \quad \square \\ & \text { Strong alcohol: } & 0.03 \mathrm{~L}\end{array}$

$\begin{array}{ll}0.20 L & \square \\ 0.33 L & \square \\ 0.13 L & \square\end{array}$

Less than once a week

How many times per week? ... . . . . . .

3. Do you drink SOFT DRINKS (coke, soda ... )

How many times per day? ... . . . ...

\section{B. MILK and DAIRY PRODUCTS}

4. Do you drink MILK? Yes $\square$

Which kind? Whole $\square$

How much? Small $(120 \mathrm{~mL})$

How many times per week? ... . . . . . .

5. Do you eat Yogurt? Yes

How much? Small $(125 \mathrm{~g})$

How many times per week? ........

6. Do you eat CHEESE? Yes

How many times per week? ... . . . . . .

6.1. HARD CHEESE(e.g., parmesan, sheep's milk, Swiss)? Yes

How much? Small serving $(30 \mathrm{~g}) \quad \square \quad$ Medium serving $(50 \mathrm{~g})$

How many times per week? ... ......

6.2. SOFT CHEESE? Yes $\square$

How much? Small serving $(50 \mathrm{~g}) \quad \square$

How many times per week? ... ......

6.3. MOZZARELLA? Yes

How much? Small serving $(60 \mathrm{~g})$

How many times per week? ... ......

\subsection{COTTAGE CHEESE? Yes}

How much? Small serving $(100 \mathrm{~g})$

How many times per week? ... . . . . .

\section{MEAT, FISH and EGGS}

7. Do you eat RED MEAT? Yes

How much? Small serving $(80 \mathrm{~g})$

How many times per week? ... . . . . .

8. Do you eat POULTRY? Yes

How much? Small serving $(80 \mathrm{~g})$

How many times per week? . . . . . . . .

9. Do you eat PORK? Yes

How much? Small serving $(50 \mathrm{~g}) \quad \square$

How many times per week? ... . . . . .

10. Do you eat FISH? $\quad$ Yes $\square$

How much? Small serving $(100 \mathrm{~g})$

How many times per week? ... . . . . .

No, never.

Less than once a week.

\section{No, never.}

Medium serving (120 g)

Less than once a week.

No, never.

Medium serving $(120 \mathrm{~g})$

Less than once a week.

No, never.

Less than once a week.

No, never.

Medium serving (150 g)

Less than once a week.
No, never.

$\begin{array}{ll}\text { Semi-skimmed } \square & \quad \text { Skimmed } \square \\ \text { Medium }(200 \mathrm{~mL}) \quad \square & \text { Large }(300 \mathrm{~mL}) \quad \square\end{array}$

Less than once a week.

Medium (150 g)

Large (180 g)

No, never.

Less than once a week. $\begin{array}{lll}0.25 L & \square & \\ 0.45 L & \square & 0.66 L \\ 0.20 L & \square & 0.30 L\end{array}$
Large serving $(70 \mathrm{~g})$

No, never.

Medium serving (70 g)

Less than once a week.

No, never.

Medium serving (125 g) $\quad \square \quad$ Large serving $(200 g)$

Less than once a week.

No, never.

Medium serving $(150 \mathrm{~g})$

Less than once a week.

Large serving (100 g)

Large serving (200 g)

Large serving $(200 \mathrm{~g})$

Large serving (160 g)

Medium serving $(100 \mathrm{~g}) \quad \square \quad$ Large serving $(150 \mathrm{~g})$

Large serving (200 g) 
11. Do you eat CURED MEATS AND SALAMI? $\quad$ Yes $\square \quad$ No, never.

How much?

$\begin{array}{llllll}\text { CURED MEAT: } & \text { Small serving }(20 \mathrm{~g}) & \square & \text { Medium serving }(40 \mathrm{~g}) & \square & \text { Large serving }(80 \mathrm{~g}) \\ \text { SALAMI: } & \text { Small serving }(15 \mathrm{~g}) & \square & \text { Medium serving }(30 \mathrm{~g}) & \square & \text { Large serving }(50 \mathrm{~g})\end{array}$

How many times per week? ....... L Less than once a week.

12. Do you eat EGGS? Yes $\square \quad$ No, never.

How many times per week? ... ...... Less than once a week.

\section{CEREALS}

13. Do you eat PASTA or RICE? $\quad$ Yes $\square \quad$ No, never.

How much? Small serving $(40-50 \mathrm{~g}) \quad \square \quad$ Medium serving $(60-80 \mathrm{~g}) \quad \square \quad$ Large serving $(100-120 \mathrm{~g})$

How many times per week? ... ..... L Less than once a week.

14. Do you eat BREAD? Yes $\square \quad$ No, never.

How much? $\quad$ Small serving $(30 \mathrm{~g}) \quad \square \quad$ Medium serving $(50 \mathrm{~g}) \quad \square \quad$ Large serving $(100 \mathrm{~g})$

How many times per week? . . . . . . . . Less than once a week.

15. Do you eat BAKERY PRODUCTS? Yes $\square \quad$ No, never.

How much? Small serving $(15 \mathrm{~g}) \quad \square \quad$ Medium serving $(30 \mathrm{~g}) \quad \square \quad$ Large serving $(45 \mathrm{~g})$

How many times per week? ... ..... L Less than once a week.

16. Do you eat POTATOES? Yes $\square \quad$ No, never.

How much? Small serving $(100 \mathrm{~g}) \quad \square \quad$ Medium serving $(150 \mathrm{~g}) \quad \square \quad$ Large serving $(200 \mathrm{~g})$

How many times per week? ........ Less than once a week.

17. Do you eat PIZZA? Yes $\square \quad$ No, never. $\square$

How much? $\quad$ Small serving $(100 \mathrm{~g}) \quad \square \quad$ Medium serving $(150 \mathrm{~g}) \quad \square \quad$ Large serving $(300 \mathrm{~g}) \quad \square$

How many times per week? ........ Less than once a week.

E. VEGETABLES, LEGUMES and FRUIT

18. Do you eat VEGETABLES or GREENS? $\quad$ Yes $\square \quad$ No, never.

How much? Small serving $(100 \mathrm{~g}) \quad \square \quad$ Medium serving $(150 \mathrm{~g}) \quad \square \quad$ Large serving $(300 \mathrm{~g}) \quad \square$

How many times per week? ........ Less than once a week.

19. Do you eat LEGUMES (beans, peas) ? $\quad$ Yes $\square \quad$ No, never.

How much?

$\begin{array}{llllll}\text { DRIED: } & \text { Small serving }(30 \mathrm{~g}) & \square & \text { Medium serving }(50 \mathrm{~g}) & \square & \text { Large serving }(70 \mathrm{~g}) \quad \square \\ \text { FRESH: } & \text { Small serving }(75 \mathrm{~g}) & \square & \text { Medium serving }(125 g) & \square & \text { Large serving }(175 g) \quad \square\end{array}$
How many times per week? ........ Less than once a week.

20. Do you eat FRESH FRUIT? Yes $\square \quad$ No, never.

How much? Small serving $(100 \mathrm{~g}) \quad \square \quad$ Medium serving $(150 \mathrm{~g}) \quad \square \quad$ Large serving $(200 \mathrm{~g}) \quad \square$

How many times per week? ........ Less than once a week.

\section{F. FATTY DRESSINGS}

21. Do you eat OLIVE OIL? Yes $\square \quad$ No, never.
How much?
1 teaspoon $(5 \mathrm{~g})$
2 teaspoons $(10 \mathrm{~g})$
2 teaspoons $(15 g)$
How many times per week? .........
Less than once a week.
22. Do you eat SEED OIL? Yes $\square$
No, never.
How much? 1 teaspoon $(5 \mathrm{~g})$

$$
2 \text { teaspoons }(10 \mathrm{~g}) \quad \square \quad 2 \text { teaspoons }(15 \mathrm{~g})
$$

How many times per week? ... ......

Less than once a week.

No, never.

23. Do you eat BUTTER? $\quad$ Yes $\square$
How much?

How many times per week? ... . . . . . Less than once a week.

Medium serving $(10 \mathrm{~g}) \quad \square \quad$ Large serving $(15 \mathrm{~g})$ 
24. Do you eat MARGARINE? Yes $\square \quad$ No, never. $\square$
How much?
Small serving $(5 \mathrm{~g})$
Medium serving $(10 \mathrm{~g})$
Large serving $(15 \mathrm{~g})$
How many times per week? ... . . . . . L Less than once a week.

G. OTHER

25. Do you eat SWEETS?

Yes $\square \quad$ No, never. $\quad \square$

How much?

Small serving $(30 \mathrm{~g})$

Medium serving $(50 g)$

Large serving $(70 \mathrm{~g})$

How many times per week? ... ... . . L Less than once a week.

26. Do you eat FRIED FOODS? Yes $\square \quad$ No, never.

How many times per week? ... . . . . . Less than once a week.

27. Do you eat FAST FOOD? Yes $\square \quad$ No, never.

Which kind?

$\begin{array}{lrlll}\text { HAMBERGER: } & \text { Medium serving }(120 \mathrm{~g}) & \square & \text { Large serving }(210 \mathrm{~g}) \\ \text { Hot Dog: } & \text { Medium serving }(120 \mathrm{~g}) & \square & \text { Large serving }(210 \mathrm{~g}) \\ \text { LOCAL STREET FOOD: } & \square\end{array}$

LOCAL STREET FOOD:

Panelle sandwich Medium serving $(200 \mathrm{~g})$

Spleen sandwich Medium serving $(250 \mathrm{~g})$

How many times per week? ... ...... Less than once a week.

\section{Appendix B}

Table A1. Procedure used to calculate energy and nutrients content from FFQ.

\begin{tabular}{|c|c|c|c|}
\hline Categories & Items & $\begin{array}{l}\text { Scotti-Bassani Atlas Reference } \\
\text { (Table Number) }\end{array}$ & MetaDieta Software Selection \\
\hline \multirow{5}{*}{ Drinks } & Coffee & Cup (n.99) & Espresso \\
\hline & Wine & Glasses 2 (n.94) & Red wine \\
\hline & Beer & Bottles and can 1 (n.95) & Lager beer \\
\hline & Strong drinks & Glasses 1 (n.93) & Vodka \\
\hline & Soft drinks & Bottles and can 2 (n.95) & Coke \\
\hline \multirow{6}{*}{$\begin{array}{l}\text { Milk and dairy } \\
\text { products }\end{array}$} & Milk & Milk (n.33) & Semi-skimmed milk \\
\hline & Yogurt & Yogurt (n.35) & Whole milk yogurt \\
\hline & Hard cheese & Cheese 2 (n.31) & Standard hard cheese serving \\
\hline & Soft cheese & Cheese 1 (n.30) & Standard soft cheese serving \\
\hline & Mozzarella & Mozzarella (n.34) & Mozzarella \\
\hline & Cottage cheese & Cottage cheese (n.32) & Cottage cheese \\
\hline \multirow{7}{*}{ Meat, fish and eggs } & Red meat & Beef steak (n.40) & Semi-fat beef \\
\hline & Poultry & Chicken breast (n.42) & Chicken breast \\
\hline & Pork & Pork steak (n.40) & Pork Sirloin Chop \\
\hline & Fish & Cod fillet (n.54) & Cod fillet \\
\hline & Cured meat & Ham (n.46) & Ham \\
\hline & Salami & Salami (n.48) & Salami \\
\hline & Eggs & Omelette (n.36) & Chicken eggs \\
\hline
\end{tabular}


Table A1. Cont.

\begin{tabular}{|c|c|c|c|}
\hline Categories & Items & $\begin{array}{l}\text { Scotti-Bassani Atlas Reference } \\
\text { (Table Number) }\end{array}$ & MetaDieta Software Selection \\
\hline \multirow{5}{*}{ Cereals } & Pasta/rice & Pasta and tomato sauce (n.22) & Semolina pasta \\
\hline & Bread & Bread (n.4) & Bread Bread (n.4) Bread \\
\hline & Bakery products & Crackers (n.1)Bread sticks (n.3) & Crackers, bread sticks \\
\hline & Potatoes & Boiled potatoes (n.28) & Boiled potatoes \\
\hline & Pizza & Pizza (n. 8) & Pizza tomato and mozzarella \\
\hline \multirow{4}{*}{$\begin{array}{l}\text { Vegetables, } \\
\text { legumes and fruits }\end{array}$} & Vegetables/greenS & Vegetable and greens (n. 61-71) & Lettuce, spinach, eggplant, zucchini, carrots \\
\hline & Dried legumes & Beans (n.26) & Beans \\
\hline & Fresh legumes & Peas (n.29) & Peas \\
\hline & Fresh Fruits & Fresh fruit (n.72-80) & Seasonal fresh fruit \\
\hline \multirow{4}{*}{ Fatty dressings } & Olive oil & Spoons, spoons and ladles (n.98) & Extra-virgin olive oil \\
\hline & Seed oil & Spoons, spoons and ladles (n.98) & Sunflower seed oil \\
\hline & Butter & Fat dressings (n.92) & Butter \\
\hline & Margarine & Fat dressings (n.92) & Margarine \\
\hline \multirow{6}{*}{ Other } & Sweets & Sweets (n.87, 88) & Standard sweets serving \\
\hline & Fried foods & French fries (n.27) & French fries \\
\hline & Fast food & & \\
\hline & Hamburger & Hamburger sandwich (n.82) & Hamburger sandwich \\
\hline & Hot dog & & Hot dog \\
\hline & Local street food & & Panelle sandwich and spleen sandwich \\
\hline
\end{tabular}

Each item was recognized by the interviewee in the food atlas, and then a pre-specified corresponding referral food was considered for calculations in the MetaDieta software.

\section{References}

1. Herbst, K.L. Subcutaneous Adipose Tissue Diseases: Dercum Disease, Lipoedema, Familial Multiple Lipomatosis, and Madelung Disease. In Endotext; Feingold, K.R., Anawalt, B., Boyce, A., Chrousos, G., de Herder, W.W., Dungan, K., Grossman, A., Hershman, J.M., Hofland, H.J., Kaltsas, G., et al., Eds.; MDText.com, Inc.: South Dartmouth, MA, USA, 2000.

2. Child, A.H.; Gordon, K.D.; Sharpe, P.; Brice, G.; Ostergaard, P.; Jeffery, S.; Mortimer, P.S. Lipoedema: An Inherited Condition. Am. J. Med. Genet. Part A 2010, 152, 970-976. [CrossRef] [PubMed]

3. Chen, S.-G.; Hsu, S.-D.; Chen, T.-M.; Wang, H.-J. Painful Fat Syndrome in a Male Patient. Br. J. Plast. Surg. 2004, 57, $282-286$. [CrossRef]

4. Földi, M.; Földi, E.; Kubik, S. Földi's Textbook of Lymphology; Elsevier: Amsterdam, The Netherlands, 2003.

5. Herbst, K.L. Lipoedema Fat and Signs and Symptoms of Illness, Increase with Advancing Stages. 2014. Available online: https:/ /www. archivesofmedicine.com/medicine/lipoedema-fat-andsigns-and-symptoms-of-illness-increase-with-advancing-stagephp (accessed on 25 March 2020).

6. Al-Ghadban, S.; Cromer, W.; Allen, M.; Ussery, C.; Badowski, M.; Harris, D.; Herbst, K. Dilated Blood and Lymphatic Microvessels, Angiogenesis, Increased Macrophages, and Adipocyte Hypertrophy in Lipoedema Thigh Skin and Fat Tissue. J. Obes. 2019, 2019, 1-10. [CrossRef]

7. Felmerer, G.; Stylianaki, A.; Hollmén, M.; Ströbel, P.; Stepniewski, A.; Wang, A.; Frueh, F.S.; Kim, B.-S.; Giovanoli, P.; Lindenblatt, N.; et al. Increased Levels of VEGF-C and Macrophage Infiltration in Lipoedema Patients without Changes in Lymphatic Vascular Morphology. Sci. Rep. 2020, 10. [CrossRef]

8. Buck, D.W., II.; Herbst, K.L. Lipoedema: A Relatively Common Disease with Extremely Common Misconceptions. Plast. Reconstr. Surg. Glob. Open 2016, 4, e1043. [CrossRef]

9. Michelini, S.; Chiurazzi, P.; Marino, V.; Dell’Orco, D.; Manara, E.; Baglivo, M.; Fiorentino, A.; Maltese, P.E.; Pinelli, M.; Herbst, K.L. Aldo-Keto Reductase 1C1 (AKR1C1) as the First Mutated Gene in a Family with Nonsyndromic Primary Lipoedema. Int. J. Mol. Sci. 2020, 21, 6264. [CrossRef]

10. De Lorenzo, A.; Gratteri, S.; Gualtieri, P.; Cammarano, A.; Bertucci, P.; Di Renzo, L. Why Primary Obesity Is a Disease? J. Transl. Med. 2019, 17, 169. [CrossRef] 
11. Di Renzo, L.; Gualtieri, P.; Alwardat, N.; De Santis, G.; Zomparelli, S.; Romano, L.; Marchetti, M.; Michelin, S.; Capacci, A.; Piccioni, A.; et al. The Role of IL-6 Gene Polymorphisms in the Risk of Lipoedema. Eur. Rev. Med. Pharmacol. Sci. 2020, 24, 3236-3244. [CrossRef]

12. Dietzel, R.; Reisshauer, A.; Jahr, S.; Calafiore, D.; Armbrecht, G. Body Composition in Lipoedema of the Legs Using Dual-Energy X-Ray Absorptiometry: A Case-Control Study. Br. J. Dermatol. 2015, 173, 594-596. [CrossRef]

13. Herbst, K.L. Rare Adipose Disorders (RADs) Masquerading as Obesity. Acta Pharmacol. Sin. 2012, 33, 155-172. [CrossRef]

14. Hardy, D.; Williams, A. Best Practice Guidelines for the Management of Lipoedema. Br. J. Community Nurs. 2017, 22, S44-S48. [CrossRef]

15. Ehrlich, C.; Iker, E.; Herbst, K.L.; Kahn, L.-A.; Sears, D.D.; Kenyon, M.; McMahon, E. Lymphedema and Lipoedema Nutrition Guide Foods, Vitamins, Minerals, and Supplements; Lymph Notes: San Francisco, CA, USA, 2015.

16. Dayan, E.; Kim, J.N.; Smith, M.L.; Seo, C.A.; Damstra, R.J.; Schmeller, W. Lipoedema—The Disease They Call FAT: An Overview for Clinicians; The Lipoedema Project at The Friedman Center for Lymphedema Research and Treatment in collaboration with Lymphatic Education \& Research Network: Boston, MA, USA, 2017.

17. Dudek, J.E.; Białaszek, W.; Ostaszewski, P. Quality of Life in Women with Lipoedema: A Contextual Behavioral Approach. Qual. Life Res. 2016, 25, 401-408. [CrossRef]

18. Reich-Schupke, S.; Schmeller, W.; Brauer, W.J.; Cornely, M.E.; Faerber, G.; Ludwig, M.; Lulay, G.; Miller, A.; Rapprich, S.; Richter, D.F.; et al. S1 Guidelines: Lipoedema. J. Dtsch. Dermatol. Ges. 2017, 15, 758-767. [CrossRef]

19. Keith, L.; Seo, C.A.; Rowsemitt, C.; Pfeffer, M.; Wahi, M.; Staggs, M.; Dudek, J.; Gower, B.; Carmody, M. Ketogenic Diet as a Potential Intervention for Lipoedema. Med. Hypotheses 2020, 110435. [CrossRef]

20. De Lorenzo, A.; Bernardini, S.; Gualtieri, P.; Cabibbo, A.; Perrone, M.A.; Giambini, I.; Di Renzo, L. Mediterranean Meal versus Western Meal Effects on Postprandial Ox-LDL, Oxidative and Inflammatory Gene Expression in Healthy Subjects: A Randomized Controlled Trial for Nutrigenomic Approach in Cardiometabolic Risk. Acta Diabetol. 2017, 54, 141-149. [CrossRef]

21. Di Renzo, L.; Rizzo, M.; Iacopino, L.; Sarlo, F.; Domino, E.; Jacoangeli, F.; Colica, C.; Sergi, D.; De Lorenzo, A. Body Composition Phenotype: Italian Mediterranean Diet and C677T MTHFR Gene Polymorphism Interaction. Eur. Rev. Med. Pharmacol. Sci. 2013, $17,2555-2565$.

22. Di Renzo, L.; Di Pierro, D.; Bigioni, M.; Sodi, V.; Galvano, F.; Cianci, R.; La Fauci, L.; De Lorenzo, A. Is Antioxidant Plasma Status in Humans a Consequence of the Antioxidant Food Content Influence? Eur. Rev. Med. Pharmacol. Sci. 2007, 11, 185-192.

23. Di Renzo, L.; Marsella, L.T.; Carraro, A.; Valente, R.; Gualtieri, P.; Gratteri, S.; Tomasi, D.; Gaiotti, F.; De Lorenzo, A. Changes in LDL Oxidative Status and Oxidative and Inflammatory Gene Expression after Red Wine Intake in Healthy People: A Randomized Trial. Mediat. Inflamm. 2015, 2015, 1-13. [CrossRef]

24. World Health Organization. Obesity: Preventing and Managing the Global Epidemic. Report of a WHO Consultation; WHO Technical Report Series; World Health Organization: Geneva, Switzerland, 2000; p. 252.

25. De Lorenzo, A.; Romano, L.; Di Renzo, L.; Di Lorenzo, N.; Cenname, G.; Gualtieri, P. Obesity: A Preventable, Treatable, but Relapsing Disease. Nutrition 2020, 71, 110615. [CrossRef]

26. Colica, C.; Merra, G.; Gasbarrini, A.; De Lorenzo, A.; Cioccoloni, G.; Gualtieri, P.; Perrone, M.A.; Bernardini, S.; Bernardo, V.; Di Renzo, L. Efficacy and Safety of Very-Low-Calorie Ketogenic Diet: A Double Blind Randomized Crossover Study. Eur. Rev. Med. Pharmacol. Sci. 2017, 21, 2274-2289.

27. De Lorenzo, A.; Di Renzo, L.; Morini, P.; de Miranda, R.C.; Romano, L.; Colica, C. New Equations to Estimate Resting Energy Expenditure in Obese Adults from Body Composition. Acta Diabetol. 2018, 55, 59-66. [CrossRef] [PubMed]

28. De Weir, J.V. New Methods for Calculating Metabolic Rate with Special Reference to Protein Metabolism. J. Physiol. 1949, $109,1$. [CrossRef] [PubMed]

29. United Nations University; World Health Organization. Human Energy Requirements: Report of a Joint FAO/WHO/UNU Expert Consultation: Rome, 17-24 October 2001; Food \& Agriculture Organization of the United Nations: Rome, Italy, $2004 ;$ Volume 1.

30. Buscemi, S.; Rosafio, G.; Vasto, S.; Massenti, F.M.; Grosso, G.; Galvano, F.; Rini, N.; Barile, A.M.; Maniaci, V.; Cosentino, L. Validation of a Food Frequency Questionnaire for Use in Italian Adults Living in Sicily. Int. J. Food Sci. Nutr. 2015, 66, 426-438. [CrossRef]

31. Alberti-Fidanza, A.; Fidanza, F. Mediterranean Adequacy Index of Italian Diets. Public Health Nutr. 2004, 7, 937-941. [CrossRef]

32. De Lorenzo, A.; Noce, A.; Bigioni, M.; Calabrese, V.; Della Rocca, D.G.; Daniele, N.D.; Tozzo, C.; Renzo, L.D. The Effects of Italian Mediterranean Organic Diet (IMOD) on Health Status. Curr. Pharm. Des. 2010, 16, 814-824. [CrossRef]

33. The Measurement and Valuation of Health Status Using EQ-5D: A European Perspective: Evidence from the EuroQol BIOMED Research Programme; Brooks, R.; Rabin, R.; de Charro, F. (Eds.) Springer: Dordrecht, The Netherlands, 2003; ISBN 9789401702331.

34. Eurool ResearchRabinEuroQol Research Foundation. EQ-5D-3L User Guide Version 2018. Available online: https://euroqol.org/ publications/user-guides (accessed on 25 March 2020).

35. Salaffi, F.; Sarzi-Puttini, P.; Girolimetti, R.; Gasparini, S.; Atzeni, F.; Grassi, W. Development and Validation of the SelfAdministered Fibromyalgia Assessment Status: A Disease-Specific Composite Measure for Evaluating Treatment Effect. Arthritis Res. Ther. 2009, 11, R125. [CrossRef]

36. la Torre, Y.S.-D.; Wadeea, R.; Rosas, V.; Herbst, K.L. Lipoedema: Friend and Foe. Horm. Mol. Biol. Clin. Investig. $2018,33$. [CrossRef] 
37. Alwardat, N.; Di Renzo, L.; Alwardat, M.; Romano, L.; De Santis, G.L.; Gualtieri, P.; Carrano, E.; Nocerino, P.; De Lorenzo, A. The Effect of Lipoedema on Health-Related Quality of Life and Psychological Status: A Narrative Review of the Literature. Eat. Weight Disord. Stud. Anorex. Bulim. Obes. 2020, 25, 851-856. [CrossRef]

38. Marshall, M.N. Sampling for Qualitative Research. Fam. Pract. 1996, 13, 522-525. [CrossRef]

39. Runkel, N.; Colombo-Benkmann, M.; Hüttl, T.P.; Tigges, H.; Mann, O.; Flade-Kuthe, R.; Shang, E.; Susewind, M.; Wolff, S.; Wunder, R.; et al. Evidence-Based German Guidelines for Surgery for Obesity. Int. J. Colorectal Dis. 2011, 26, 397-404. [CrossRef]

40. Seifried, H.E.; Anderson, D.E.; Fisher, E.I.; Milner, J.A. A Review of the Interaction among Dietary Antioxidants and Reactive Oxygen Species. J. Nutr. Biochem. 2007, 18, 567-579. [CrossRef]

41. Tufts, H.R.; Harris, C.S.; Bukania, Z.N.; Johns, T. Antioxidant and Anti-Inflammatory Activities of Kenyan Leafy Green Vegetables, Wild Fruits, and Medicinal Plants with Potential Relevance for Kwashiorkor. Evid. Based Complementary Altern. Med. 2015, 2015, 807158. [CrossRef]

42. Sergeev, I.N. Vitamin D Status and Vitamin D-Dependent Apoptosis in Obesity. Nutrients 2020, 12, 1392. [CrossRef]

43. Butovskaya, M.; Sorokowska, A.; Karwowski, M.; Sabiniewicz, A.; Fedenok, J.; Dronova, D.; Negasheva, M.; Selivanova, E.; Sorokowski, P. Waist-to-Hip Ratio, Body-Mass Index, Age and Number of Children in Seven Traditional Societies. Sci. Rep. 2017, 7. [CrossRef]

44. Kyle, U.G.; Bosaeus, I.; Lorenzo, A.D.D.; Deurenberg, P.; Elia, M.; Gómez, J.M.; Heitmann, B.L.; Kent-Smith, L.; Melchior, J.-C.; Pirlich, M.; et al. Bioelectrical Impedance Analysis-Part II: Utilization in Clinical Practice. Clin. Nutr. 2004, 23, 1430-1453. [CrossRef]

45. Boghossian, N.S.; Yeung, E.H.; Mumford, S.L.; Zhang, C.; Gaskins, A.J.; Wactawski-Wende, J.; Schisterman, E.F. Adherence to the Mediterranean Diet and Body Fat Distribution in Reproductive Aged Women. Eur. J. Clin. Nutr. 2013, 67, 289-294. [CrossRef]

46. Wold, L.E.; Hines, E.A.; Allen, E.V. Lipoedema of the Legs; a Syndrome Characterized by Fat Legs and Edema. Ann. Intern. Med. 1951, 34, 1243-1250. [CrossRef]

47. Ebbeling, C.B.; Swain, J.F.; Feldman, H.A.; Wong, W.W.; Hachey, D.L.; Garcia-Lago, E.; Ludwig, D.S. Effects of Dietary Composition on Energy Expenditure during Weight-Loss Maintenance. JAMA 2012, 307, 2627-2634. [CrossRef]

48. Di Renzo, L.; Cinelli, G.; Dri, M.; Gualtieri, P.; Attinà, A.; Leggeri, C.; Cenname, G.; Esposito, E.; Pujia, A.; Chiricolo, G.; et al. Mediterranean Personalized Diet Combined with Physical Activity Therapy for the Prevention of Cardiovascular Diseases in Italian Women. Nutrients 2020, 12, 3456. [CrossRef] 